\title{
Optimization of EnBase Fed-Batch Cultivation to Improve Soluble Fraction Ratio of $\alpha$-Luffin Ribosome Inactivating Protein
}

\author{
Farzaneh Barkhordari ${ }^{1,2}{ }^{\dagger}$, Mozhgan Raigani ${ }^{1 \dagger}$, Yeganeh Talebkhan Garoosi ${ }^{1}$, Fereidoun Mahboudi ${ }^{1}$, \\ Fatemeh Davami ${ }^{1^{*}}$ \\ ${ }^{1}$ Biotechnology Research Center, Pasteur Institute of Iran, Tehran, Iran \\ ${ }^{2}$ Department of Biology, Faculty of Sciences, Science and Technology Branch, Islamic Azad University, \\ Tehran, Iran
}

"Corresponding author: Fatemeh Davami, Biotechnology Research center, Pasteur Institute of Iran, 12 Farvardin Ave., Enghelab Square, Tehran, Iran. Tel: +982166953315, Fax: +98 21 66480780,E-mail: f_davami@pasteur.ac.ir

${ }^{\dagger}$ These authors contributed equally to this work.

Received: 16 Feb. 2016; Revised: 4 Feb. 2017; Accepted: 17 Mar. 2018; $\quad$ Published online: 18 Apr. 2018

\begin{abstract}
Background: The increase of the protein expression via ribosomal manipulation is one of the suggested cellular mechanisms involved in EnBase fed-batch mode of cultivation. However, this system has not been implemented for cytotoxic proteins. Objectives: Here, the expression pattern of $\alpha$-Luffin, a ribosome inactivation protein (RIP) with an innate toxicity, was investigated in EnBase system and the effect of low temperature cultivation on the increase of $\alpha$-Luffin solubility was determined.

Materials and Methods: The encoding cDNA for mature $\alpha$-Luffin was synthesized and subcloned into pET28a plasmid under the control of $\mathrm{T} 7$ promoter. The E. coli expression yield in EnBase ${ }^{\circledR}$ Flo fed-batch system was compared with traditional batch mode at two temperatures: $25^{\circ} \mathrm{C}$ and $30^{\circ} \mathrm{C}$. Sampling was performed at several time intervals and solubility of recombinant-protein was checked on SDS-PAGE in pellet and supernatant samples. The purification of recombinant protein was performed by Ni-NTA column.

Results: In fed-batch cultivation mode, the early incubation time was desirable at $30^{\circ} \mathrm{C}$ whereas the maximum amount of soluble $\alpha$-Luffin was achieved from the extended protein synthesis period (12 and $24 \mathrm{~h}$ post induction) at $25^{\circ} \mathrm{C}$.

Conclusions: Our founding showed that EnBase had a greater efficacy in producing higher soluble protein ratios compared to batch cultivation growth rate, however for cytotoxic proteins, incubation temperature and time need to be optimized. Owing to the advantages of natural toxins from RIP family for producing anticancer immune-conjugates, well optimization of this protein expression is of importance regarding industrial aspects. The optimized condition proposed here is promising in terms of large scale soluble production of $\alpha$-Luffin without the need for refolding.

Keywords: $\alpha$-Luffin, E. coli expression, Fed-batch cultivation, Ribosome inactivating proteins
\end{abstract}

\section{Background}

Ribosome-inactivating proteins (RIPs) are highly potent toxins able to inhibit protein synthesis irreversibly via ribosome inactivation. Although RIPs are usually originated from plants, bacteria and fungi, they have a wide distribution in nature and many clinical efficacies have been reported worldwide. Besides a broad spectrum of antibacterial (1), antifungal (2) and anti-viral (3) functions, a variety of antitumor(4-6) immunosuppressive (7) and antifertility effects $(7,8)$ have been reported from RIPs. Many RIP-producing species are present in plant families such as Euphorbiaceae, Cucurbitaceae, Poaceae and Caryophyllale (9). To date three principle categories of RIPs have been identified from plant resources which have structural differences: Type I RIPs consist of single chain polypeptides of approximately 30 $\mathrm{kDa}$; Double chained RIPs of around $60 \mathrm{kDa}$ are in type II category with an A chain catalytic domain common with type I and a B chain binding domain (10); Type III RIPs, synthesized as inactive precursors, undergo proteolytic process before generating an active RIP (11). No clinical indications have yet been reported for

Copyright (C 2017 The Author(s); Published by National Institute of Genetic Engineering and Biotechnology. This is an open access article, distributed under the terms of the Creative Commons Attribution-NonCommercial 4.0 International License (http://creativecommons.org/licenses/ by-nc/4.0/) which permits others to copy and redistribute material just in noncommercial usages, provided the original work is properly cited. 
the third category. Among these three categories, type I RIPs, have been broadly studied in biomedical fields for targeted drug delivery of immunotoxins in cancer immunotherapy. Luffin is a member of type I RIPs with various reported medical effects such as anti-tumor, antiAIDS, miscarriage induction and anti-fungal activities (2, 12-16). Two different glycoproteins were fractionated from Luffa cylindrica seeds, Luffin-a and Luffin-b with molecular weight of 28 and $28.8 \mathrm{kDa}$, respectively.

Cancer as the leading cause of death all over the world is a critical issue for health authorization systems. Many attempts have been made to reduce the patients suffering and financial burdens by reducing the duration and complication of the disease. One of the promising approaches in this regard is the targeted cancer therapy, which is mainly focused on using antibodies designed for cancer cell eradication. Conjugation of monoclonal antibodies $(\mathrm{mAb})$ with different cytotoxic compounds has made a second generation of antibodies with considerable success in oncology. Many toxins have been investigated as candidates for producing antibody drug conjugates but up to now only four groups have gained the approval to enter clinical trials $(17,18)$. The highly toxic and potent natural compounds could be of great value for establishing anticancer immunotoxins based on natural conjugates (19-22).

The use of native plant-derived toxins from RIPs family may be a challenging issue in terms of heterogeneity in catalytic activities due to the variety of isoforms in one herbal extraction. Furthermore, limitations in natural resources and complicated purification process may cause more restrictions.

Accordingly, recombinant expression of these proteins seemed to be more reasonable using a suitable expression system. Considering relatively small size $(28 \mathrm{kDa})$ and no disulfide bond in this protein, the prokaryotic Escherichia coli system has enough capability to its production but most studies have reported the protein accumulation in inclusion bodies which means the need for refolding approaches $(23,24)$.

Unlimited growth in density of $E$. coli cells in conventional batch cultivation mode is often associated with incorrect protein folding due to the unrestricted protein synthesis (25). Utilizing strong promoters as the routine approach in E. coli expression system is likely to produce great concentrations of desired proteins and formation of insoluble protein aggregates. Since the expression of protein in its soluble format is more desirable considering no need for further refolding steps different approaches have been applied to address this problem (26). Reducing rate of protein synthesis by decreased inducer concentration, induction at lower temperatures (27), medium optimization (28), co-expression of chaperons (29) and foldases (30) and the use of fusion tags (31) have been investigated in several studies.

Media optimization techniques were firstly performed by using high nutrient contents along with enhanced buffering as in Terrific (32). Nevertheless, this approach is deficient in supplying adequate nutrient concentrations for the cells due to the toxic effects on them and the need for constant feeding which is just applicable in the bioreactor process. In another media optimization approach the substrate-limited fed-batch cultivation techniques are used. These techniques are based on regulating growth rate by continuously and gradually feeding the culture by essential nutrients such as glucose $(33,34)$.

However, to our best knowledge few investigations have yet been focused on applying a soluble expression promoting system for the plant-derived toxins from RIPs family $(3,6)$.

\section{Objectives}

In this study, EnBase Flo fed-batch system with an enzymatic slow release of glucose was applied. Thus, the main focus of this study was to establish a soluble expression procedure of $\alpha$-Luffin in E. coli fed-batch expression mode.

\section{Materials and Methods}

\subsection{Cloning of $\alpha$-Luffin $c D N A$}

Mature alpha Luffin encoding cDNA was extracted from DNA data bank, synthesized and cloned into the appropriate cloning vector, pEASY-blunt vector (Transgen Biotech Co., LTD), after codon optimization for protein expression in E. coli cells. NdeI and XhoI restriction sites were designed at $5^{\prime}$ and $3^{\prime}$ ends of the gene, respectively.

\subsection{Subcloning of $\alpha$-Luffin Gene Fragment}

After restriction digestion analysis, the confirmed synthesized gene was subcloned into the expression vector, pET28a (Novagen, USA) under the control of T7 promoter and fused to the $6 \mathrm{x}$-histidine tag. Recombinant clone was selected through further restriction digestions and sequencing with $\mathrm{T} 7$ sequencing forward and reverse primers.

\subsection{Pilot Protein Expression Experiment}

Recombinant construct containing $\alpha$-Luffin cDNA was transformed into E. coli BL21 DE3 cells. Single grown colonies were inoculated into Luria-Bertani (LB) broth media containing $30 \mu \mathrm{g} \cdot \mathrm{mL}^{-1}$ kanamycin. 
Inoculated media were shaken at $180 \mathrm{rpm}$ for $2-3 \mathrm{~h}$ at $37{ }^{\circ} \mathrm{C}$ until optical density at $600 \mathrm{~nm}$ reached to 0.5 0.7 . One milliliter of medium was centrifuged and the bacterial pellet was kept at $-20{ }^{\circ} \mathrm{C}$. IPTG was added to the medium at the final concentration of $0.5 \mathrm{mM}$. Bacterial pellet was harvested after $4 \mathrm{~h}$ incubation at 37 ${ }^{\circ} \mathrm{C}$ on the shaker and stored at $-20{ }^{\circ} \mathrm{C}$.

\subsection{Batch Protein Expression}

For batch protein expression, single recombinant colonies were inoculated into $5 \mathrm{~mL}$ LB broth media containing $30 \mu \mathrm{g} \cdot \mathrm{mL}^{-1}$ kanamycin and incubated overnight $(16 \mathrm{~h})$ at $37^{\circ} \mathrm{C} .0 .1$ volume of the grown medium $(5 \mathrm{~mL})$ was inoculated into $50 \mathrm{~mL} \mathrm{LB}$ broth in $500 \mathrm{~mL}$ flasks and incubated at $200 \mathrm{rpm}$ for 2.5-3 h until $\mathrm{OD}_{600}$ reached to $0.5-0.7$. Final $0.5 \mathrm{mM}$ concentration of IPTG was added to the medium at this time. The above protocol was done at 25,30 and $37^{\circ} \mathrm{C}$.

\subsection{Fed-batch Protein Expression}

For fed-batch cultivation, EnPresso tablet cultivation kit (BioSilta, Finland) was used according to the manufacturer's instruction. The EnBase Flo system is based on enzymatic release of glucose by glucoamylase enzyme. In brief, single colonies were inoculated in $5 \mathrm{~mL} \mathrm{LB}$ broth for $6-8 \mathrm{~h}$ and incubated at $37{ }^{\circ} \mathrm{C}$ overnight. The contents of the white bag (2 tablets containing media components) were added to $50 \mathrm{~mL}$ of sterile water in a shake flask together with appropriate antibiotic (kanamycin). 0.1 volume of the grown medium was inoculated into the above prepared culture medium. $25 \mu \mathrm{L}$ of EnZ l'm (glucoamylase provided with BioSilta products) was added to the culture and the flask was shaken rapidly on a shaker incubator at $200 \mathrm{rpm}$. After overnight incubation, the inducing agent (black bag containing booster tablet for optimal $\mathrm{pH}$ condition) and $50 \mu \mathrm{L}$ of EnZ l'm were added to the medium. Cultivation continued for protein expression and sampling was performed at the time points of 0,2 , 4, 8, 12 and 24h. Media were centrifuged and bacterial pellet was collected and stored at $-20{ }^{\circ} \mathrm{C}$.

\subsection{Protein Analysis}

After harvesting E. coli induced cells from the culture medium through centrifugation at $6,000 \times \mathrm{g}(10 \mathrm{~min})$, in order to check the solubility of recombinant protein (r-protein), cells were resuspended in TE buffer $(25 \mathrm{mM}$ Tris, $1 \mathrm{mM}$ EDTA, $\mathrm{pH}$ 8.0) and sonicated for 4 cycles of $30 \mathrm{sec}$ bursts and $30 \mathrm{~second}$ intervals. The sonicated sample was centrifuged at $12,000 \times \mathrm{g}$ for $20 \mathrm{~min}$ at 4 ${ }^{\circ} \mathrm{C}$ to isolate the soluble fraction from the pellet. Total protein concentration of each sample was measured using absorbance at $280 \mathrm{~nm}$ and samples were analyzed on $12 \%$ SDS-PAGE stained with Coomassie Brilliant Blue G-250. The resulting cell density was the same in all samples, by adjusting the volume of Tris buffer per each. Therefore, protein productivity per cell in different samples could be compared on the basis of the protein band thickness.

\subsection{Confirmation of Expressed Recombinant Protein}

Cellular pellet was run on $12 \%$ SDS-PAGE and westernblotting was performed using mouse anti-His antibody, Penta-His HRP Conjugate, (QIAGEN, USA).

\subsection{Protein Purification Using Ni-NTA Column}

E. coli cells were resuspended in lysis buffer $\left(2-5 \mathrm{~mL} . \mathrm{g}^{-}\right.$ 1), $50 \mathrm{mM} \mathrm{NaH}_{2} \mathrm{PO}_{4}$ (pH 8.0), containing $300 \mathrm{mM} \mathrm{NaCl}$ and $20 \mathrm{mM}$ imidazole in order to increase the purity of recombinant protein and to minimize binding of undesired contaminating proteins. Bacterial suspension was sonicated according to the protocol described above and centrifuged at $10,000 \times \mathrm{g}(20 \mathrm{~min})$ at $4{ }^{\circ} \mathrm{C}$ to remove cellular debris. Soluble fraction was loaded into the column containing Ni-NTA superflow resin (QIAGEN, USA) and flow through sample was saved for running on SDS-PAGE. The loaded column was washed with $50 \mathrm{mM} \mathrm{NaH}_{2} \mathrm{PO}_{4}$ containing $300 \mathrm{mM} \mathrm{NaCl}$ and $40 \mathrm{mM}$ imidazole and the fraction was collected for checking on SDS-PAGE. Recombinant protein was eluted from the column with the elution buffer containing $250 \mathrm{mM}$ imidazole.

\section{Results}

\subsection{Cloning of Mature $\alpha$-Luffin}

Figure 1 shows successfully subcloned $\alpha$-Luffin cDNA

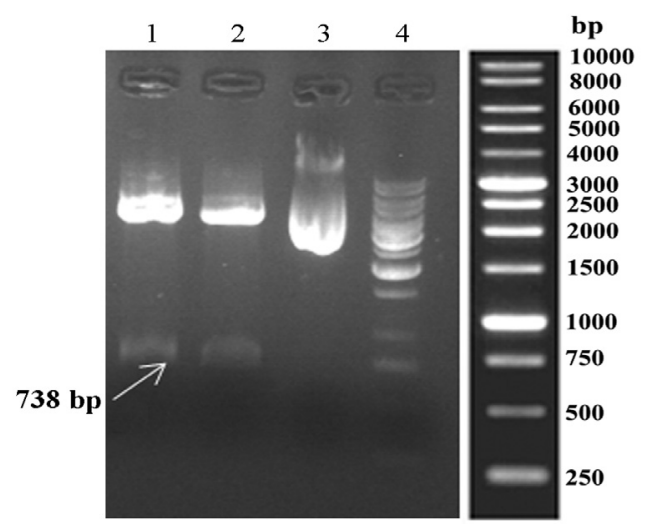

Figure 1. Restriction analysis of pET28a- $\alpha$-Luffin construct by gel electrophoresis. Lane 1 and 2, NdeI/XhoI digested plasmids (different clones); Lane 3, Undigested plasmid; Lane 4, DNA size marker (1-kb DNA ladder Fermentas ${ }^{\circledR}$ SM0311). 


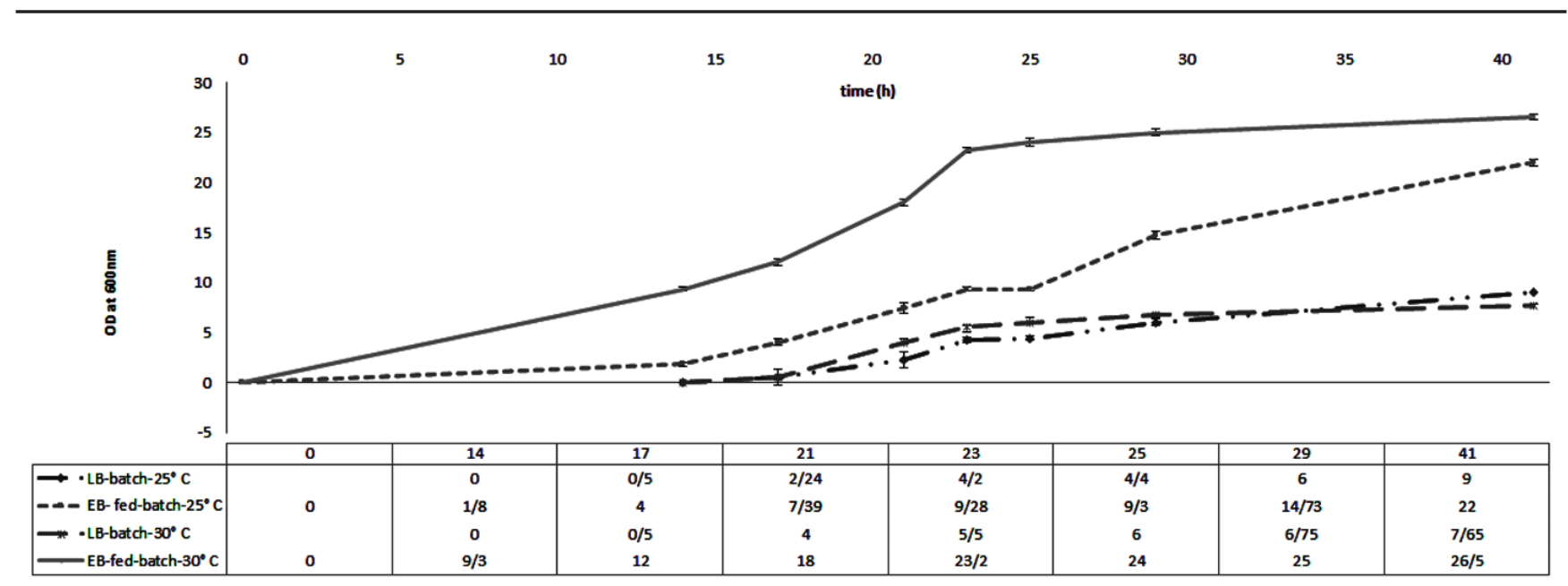

Figure 2. The effect of $\alpha$-Luffin expression at different temperatures on bacterial cell density (OD600) through EnBase fed-batch and LB batch systems. $\mathrm{EB}=$ EnBase Flo medium, $\mathrm{LB}=$ Luria-Bertani medium. E. coli colonies grown in LB media were induced with $0.5 \mathrm{mM}$ IPTG when optical density was 0.5 at 600 . The time point of induction $(0.5 \mathrm{mM}$ IPTG) is indicated with a dashed vertical line. In EB cultures, the medium was also supplemented with the booster, at the same time of induction. EB-fed-batch cultures were grown for $17 \mathrm{~h}$ before induction whereas LB cultures were incubated for $3 \mathrm{~h}$ before induction. All cultures were continued to grow until $24 \mathrm{~h}$ after induction.

(amino acids 21 to 26) into pET28a vector through NdeIXhoI restriction sites. The digestions of the expression plasmid with these restriction enzymes afterward, resulted in two fragments sized; 738 and $5369 \mathrm{bps}$ which stand for $\alpha$-Luffin and pET28a backbone, respectively. Final sequencing of the construct confirmed the presence and correct orientation of insert in the vector (data not shown).

As illustrated in Figure 2 the effect of $\alpha$-Luffin expression was determined on $E$. coli cell density using EnBase Flo fed-batch and conventional batch cultures in two different temperatures $\left(25\right.$ and $\left.30^{\circ} \mathrm{C}\right)$. EnBase Flo (EB) fed-batch and LB batch cultures were respectively grown for $17 \mathrm{~h}$ and $3 \mathrm{~h}$ before induction. Therefore, the $\mathrm{OD}_{600}$ values determined at 21, 23, 25, 29 and $41 \mathrm{~h}$ from fed-batch culture start points stand for $4,6,8,12$ and $24 \mathrm{~h}$ post induction for both LB batch as well as EB fed-batch cultures.

\subsection{Bacterial Growth}

As seen in Figure 2, except for fed-batch mode at 25 ${ }^{\circ} \mathrm{C}$, the rate of cell density growth was reduced $6 \mathrm{~h}$ post induction in all examined conditions due to the slight toxicity of $\alpha$-Luffin expression for $E$. coli. In batch culture, condition the increase of cell density occurred with a slightly sharper slope at $30^{\circ} \mathrm{C}$ compared to $25^{\circ} \mathrm{C}$ and it continued to a steady state condition $12 \mathrm{~h}$ post induction (Fig. 2). In EB fed-batch mode, however the difference between two temperature culture conditions was more drastic. There was a distinct OD difference between two applied temperatures at the time of induction; $\mathrm{OD}_{600}$ of 4 and $12 \mathrm{~h}$ for $25^{\circ} \mathrm{C}$ and $30^{\circ} \mathrm{C}$, respectively and this difference is almost preserved during the whole culture duration. In $30{ }^{\circ} \mathrm{C}$ fed-batch condition, cells reached a nearly saturated point at $6 \mathrm{~h}$ post induction and after that they almost stayed in a steady condition whereas in $25^{\circ} \mathrm{C}$, cells continued the growth with almost the same speed for the whole culture duration time. Finally, cells reached a $24 \mathrm{~h}$ post induction $\mathrm{OD}_{600}$ of 26.5 at $30^{\circ} \mathrm{C}$ and an OD of 22 at $25^{\circ} \mathrm{C}$.

\subsection{Effect of Temperature on $\alpha$-Luffin Expression in Different Culture Modes}

Total protein production in LB batch and EB fedbatch systems were analyzed on SDS-PAGE (Fig. 3). The approximate $28 \mathrm{kDa}$ band on SDS PAGE (Fig. 3 ) represented successful expression of His- $\alpha$-Luffin recombinant fusion protein in BL21 (DE3) clones during different hours after induction. This band was absent in control negative clones transformed with pET28a vector alone and in before induction samples except for a leaky expression in $30{ }^{\circ} \mathrm{C}$ of fed-batch culture (panel $\mathrm{B}$ lane 3). The slight difference between the induced protein size and the theoretical calculated weight based on cDNA deduced amino acid sequence (26.6 kDa), was due to the N-terminal fused His-Tag from pET28a. As represented in Figure $3,30^{\circ} \mathrm{C}$ temperature condition resulted in higher expression of recombinant $\alpha$-Luffin 
in both fed-batch and batch culture modes and indeed at $25{ }^{\circ} \mathrm{C}$ of batch culture no obvious expression of the recombinant protein was observed.

As all samples were diluted to an equal cell concentration before lysis procedure and loading on gel, it is clear that in spite of toxic effect of $\alpha$-Luffin for $E$. coli cells, the fed-batch condition was still able to produce higher levels of protein expression per cell compared to the conventional batch mode.
Furthermore, following cell lysis analysis up to $24 \mathrm{~h}$ post induction for both culture modes (batch and fed-batch) the expression per cell continued to be in the same range for $4,6,8,12$ and $24 \mathrm{~h}$ post induction although totally at a higher level with fed-batch mode. No significant increase in total protein amount was observed after applying a $24 \mathrm{~h}$ incubation period. The higher expression level in fed-batch at $30^{\circ} \mathrm{C}$ besides elevated cellular densities in the same condition

A

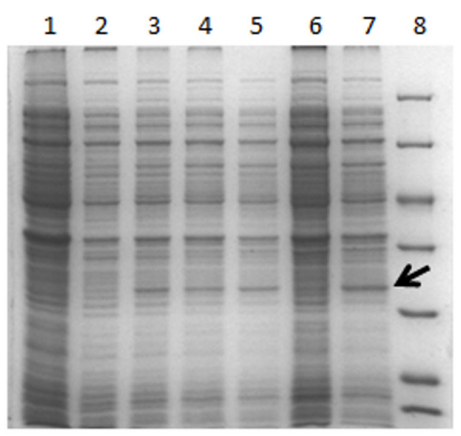

\section{B}

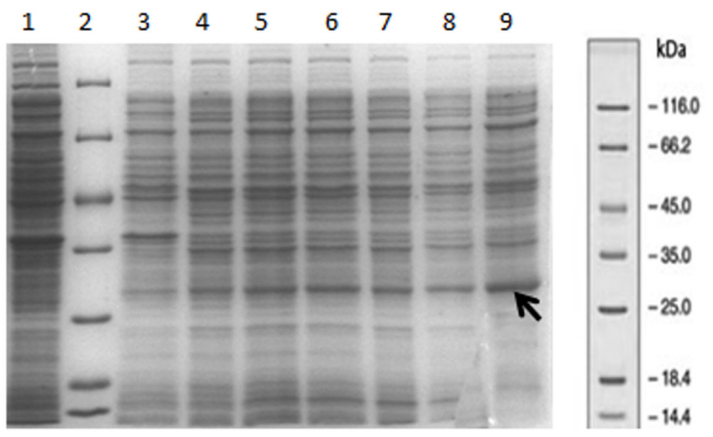

C

D
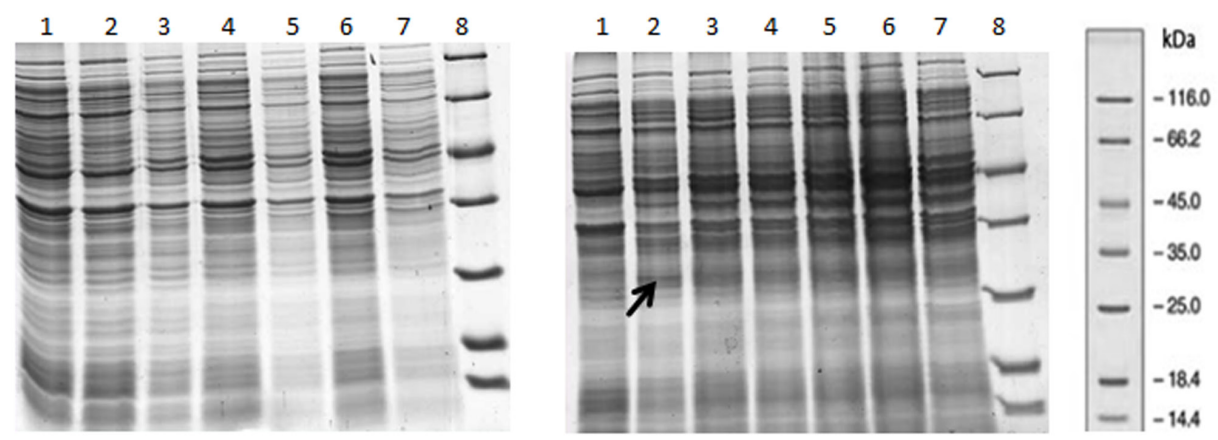

Figure 3. Coomassie stained SDS-PAGE analysis of cell lysates from $\alpha$-Luffin producing E. coli BL21 (DE3) clones in different temperatures, time and mode of culture. Panel A: LB batch culture mode in $30{ }^{\circ}$ C. Lane1, Control (E. coli/pET28a only); Lane 2, Cell lysates before IPTG induction; Lane 3, Cell lysates $4 \mathrm{~h}$ post induction; Lane 4, Cell lysates $6 \mathrm{~h}$ post induction; Lane 5, Cell lysates $8 \mathrm{~h}$ post induction; Lane 6 , Cell lysates $12 \mathrm{~h}$ post induction; Lane 7 , Cell lysates $24 \mathrm{~h}$ post induction; Lane 8 , Protein marker SM0671. Panel B: EB Fed-batch culture mode in $\mathbf{3 0}^{\circ} \mathrm{C}$. Lane1, Control (E. coli/pET28a only); Lane 2, Protein marker SM0671; Lane 3, Cell lysates before IPTG induction; Lane 4, Cell lysates 4h post induction; Lane 5, Cell lysates 6h post induction; Lane 6, Cell lysates 8h post induction; Lane 7, Cell lysates total protein $10 \mathrm{~h}$ post induction; Lane 8 , Cell lysates total protein $12 \mathrm{~h}$ post induction; Lane 9, Cell lysates total protein $24 \mathrm{~h}$ post induction. Panel C: LB batch culture mode in $\mathbf{2 5}^{\circ} \mathrm{C}$. Lane1, Control (E. coli/ pET28a only); Lane 2, Cell lysates total protein before IPTG induction; Lane 3, Cell lysates total protein $4 \mathrm{~h}$ post induction; Lane 4, Cell lysates total protein $6 \mathrm{~h}$ post induction; Lane 5, Cell lysates total protein $8 \mathrm{~h}$ post induction; Lane 6, Cell lysates total protein $12 \mathrm{~h}$ post induction; Lane 7, Cell lysates total protein $24 \mathrm{~h}$ post induction; Lane 8, Protein marker SM0671. Panel D: EB Fed-batch culture mode in $\mathbf{2 5}^{\circ} \mathrm{C}$. Lane1, Cell lysates total protein before IPTG induction; Lane 2, Cell lysates total protein $4 \mathrm{~h}$ post induction; Lane 3, Cell lysates total protein $6 \mathrm{~h}$ post induction; Lane 4, Cell lysates total protein $8 \mathrm{~h}$ post induction; Lane 5, Cell lysates total protein $10 \mathrm{~h}$ post induction; Lane 6 , Cell lysates total protein $12 \mathrm{~h}$ post induction; Lane 7 , Cell lysates total protein $24 \mathrm{~h}$ post induction; Lane 8, Protein marker Thermo science \#26610. All samples were diluted to equal cell concentration before lysis and loading on gel. The position of $28.8 \mathrm{kDa}$ His- $\alpha-$ Luffin is indicated by arrows. 
(Fig. 2) signified greater total recombinant $\alpha$-Luffin expression in this condition.

\subsection{Different Distribution Patterns of $\alpha$-Luffin in} Soluble Fraction in Different Culture Modes

The distribution of the recombinant protein expressed at different temperatures of two different culture modes was investigated to estimate the effect of these different conditions on protein solubility. Sampling was also continued till $24 \mathrm{~h}$ post induction to identify an optimal length of incubation (Fig. 4).

As illustrated in Figure 4 (panel A and B), in LB batch cultivation at $30^{\circ} \mathrm{C}$, desired protein was mostly present in pellet fractions in all sampling times until $24 \mathrm{~h}$ post induction. During two last sampling time points (12 and $24 \mathrm{~h}$ ) a slight increase was observed in total protein production and accordingly soluble and pellet fractions but solubility ratio did not increase.

In EB fed-batch culture at $30{ }^{\circ} \mathrm{C}$ (Fig. 4 panels $\mathrm{C}$ and $\mathrm{D}$ ), higher expression of $\alpha$-Luffin was seen in all sampling time points compared to LB batch mode at $30{ }^{\circ} \mathrm{C}$. The expressed recombinant $\alpha$-Luffin was distributed in both pellets and soluble fractions of all samples taken at 4,6 and $8 \mathrm{~h}$ post induction. At the hours of 12 and 24 however the soluble fraction was drastically reduced.

In $25^{\circ} \mathrm{C}$ fed-batch cultivation (Fig. 4 panels $\mathrm{E}$ and F), interestingly enough, the ratio of recombinant protein was significantly increased in soluble fraction compared to the pellet in 12 and $24 \mathrm{~h}$ after induction.
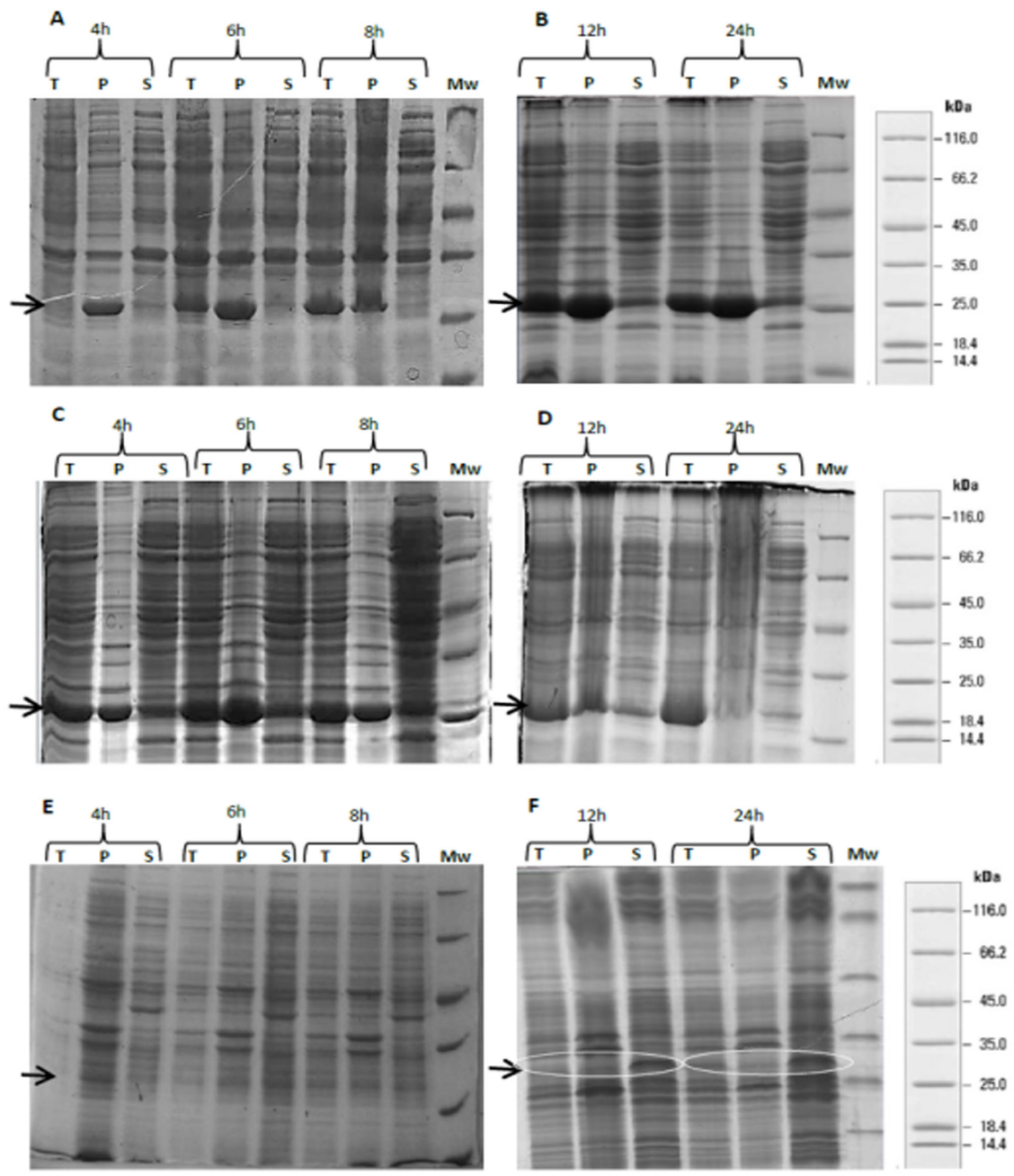

Figure 4. Coomassie stained SDS-PAGE analysis of $\alpha$-Luffin producing $E$. coli BL21 (DE3) clones in different temperatures using different cultivation media; the distribution of total cell lysates, pellet and soluble fractions during different time intervals post induction. $\mathrm{T}=$ total $E$. coli lysate, $\mathrm{P}=$ pellet, $\mathrm{S}=$ soluble fraction, $\mathrm{Mw}=$ Protein marker Thermo science \#26610. Panel A and B: LB batch culture mode in $30{ }^{\circ} \mathbf{C}$; Panel C and D: EB Fed-batch culture mode in $30{ }^{\circ} \mathrm{C}$; Panel E and F: EB Fed-batch culture mode in $25^{\circ} \mathrm{C}$. 


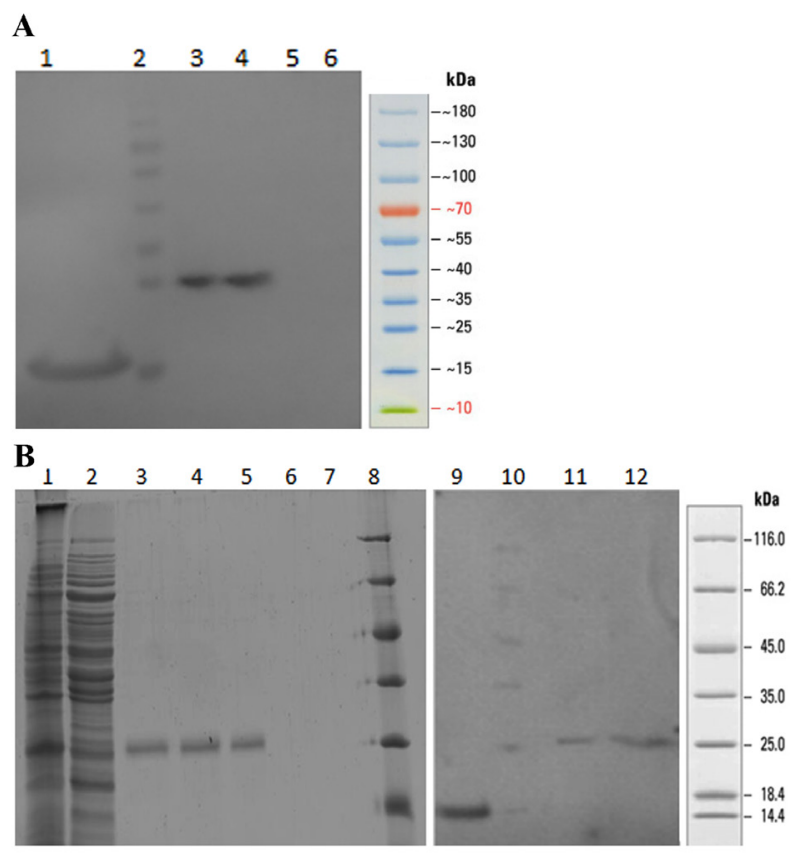

However, in early phase sampled tests no indictable difference was seen in total, pellet and soluble fractions.

The results indicated that the highest ratio of soluble to pellet fraction of $\alpha$-luffin was obtained after 12 and $24 \mathrm{~h}$ in EB fed-batch at $25^{\circ} \mathrm{C}$ temperature.

\subsection{Western Blotting}

Western blot analysis was performed for further confirmation of expression using an anti-His antibody conjugated with alkaline phosphatase (Fig. 5A). An $18 \mathrm{kDa}$ His-conjugated protein was investigated as a control His tagged protein. The $28 \mathrm{kDa}$ band was observed in western blot analysis which indicated Histag fused- $\alpha$-Luffin protein.

\subsection{NTA Purification}

As shown in Figure 5B purification procedure was applied on soluble fraction of $\alpha$-Luffin producing BL21 lysates from batch and EnBase fed-batch process through which successfully a single $28 \mathrm{kDa}$ band was observed on SDS- PAGE and confirmed by anti-His Western blotting. The purification procedure was intentionally set to purify the protein in its soluble, native form. As illustrated in Figure 5B the amount of soluble $\alpha$-Luffin recovered form fed-batch mode was greater compared to the batch cultivation.

\section{Discussion}

The use of $\mathrm{mAb}$ directed delivery can confer a therapeutic index to highly potent cytotoxic drugs such as plant sourced RIP family. Thus, these highly toxic
Figure 5. Western blot analysis of total cell lysates and purified $\alpha$-Luffin. A: Western blot analysis on total cell lysates of $\alpha$-Luffin producing E. coli BL21 clones cultured in the fed-batch mode. Proteins were visualized with an anti-His antibody conjugated with alkaline phosphatase and DAB substrate. Lane 1, Control positive, an $18 \mathrm{kDa}$ His-tagged protein; Lane 2, protein marker Thermo science \#26616; Lanes 3 and 4, E. coli BL21 cell lysates $6 \mathrm{~h}$ after induction; Lane 5, Control negative before induction; Lane 6, Control negative E. coli/pET28a alone. B: SDSPAGE (Lanes 1-8) and Western blot (Lanes 9-12) analysis of purified $\alpha$-Luffin from fed batch process. Lane 1, Fed-batch soluble fraction (initial sample); Lane 2, NTA flow through sample; Lanes 3-7, Elution fractions from NTA column representing purified $\alpha$-Luffin; Lane 9, His-tagged control protein (18 kDa); Lanes 11 and 12, NTA purified $\alpha$-Luffin from fed-batch soluble fraction; Lanes 8 and 10, Protein size marker Thermo science \#26610.

and potent natural compounds could be of great value for establishing anticancer immunotoxins based on natural conjugates (19-22). This considerable clinical advantage along with other therapeutic efficacies of RIP derived toxins like anti-AIDS, immunomodulatory functions, etc. is the reason for huge research interest to have access to this group of proteins from natural origin, in fledging steps, and now from recombinant technology.

As illustrated, in this study the efficacy of EnBase fed-batch mode for the production of a toxic protein $(\alpha$-Luffin) and the optimization of the cultivation temperature and incubation time was investigated for the first time.

As it is suspected from their highly toxic nature, RIP family toxins show their toxic effects on producing host cells. This fact is highly pronounced with more cytotoxic derivatives like Luffin-a and b from Luffa cylindrical (12-16).

In this study the growth rate prohibition effect was seen as a distinct reduction in cell density upward slope $6 \mathrm{~h}$ post induction both in 30 and $25{ }^{\circ} \mathrm{C}$ in batch cultivation mode as well as $30{ }^{\circ} \mathrm{C}$ in fed-batch cultivation which is in accordance with previous studies $(5,25)$. Interestingly however, the upward shift in $\mathrm{OD}_{600}$ values was remained with a stable slope in fed-batch mode when ran at $25^{\circ} \mathrm{C}$. This result indicates that in the latter cultivation condition the cytotoxic effect of Luffin expression was less pronounced. The less cytotoxic effect at lower temperatures may be explained by the fact that the number of functional ribosomes in the cell 
are more at lower temperatures (35) and $\alpha$-Luffin is a ribosome inactivating protein so when more ribosomes are available the inhibiting effect are probably shielded. Therefore, the ribosome inhibitory toxic effect is less apparent at the low temperature cultivation. In fedbatch mode, at $24 \mathrm{~h}$ post induction in $25^{\circ} \mathrm{C}$, the final cell density $\left(\mathrm{OD}_{600} 22\right)$ slightly lower than what was observed in $30{ }^{\circ} \mathrm{C}\left(\mathrm{OD}_{600} 26.5\right)$, with a steady upward shift during the process (Fig. 2).

Some previous studies have mentioned the toxic effect of RIPs on prokaryotic ribosomes $(5,36,37)$. Nevertheless there exists a controversy in this regard from other published results. Based on our observations (demonstrated in Fig. 2) lower temperature cultivation $\left(25^{\circ} \mathrm{C}\right)$ could reduce the toxic effect of $\alpha$-Luffin on $E$. coli cells only if it was performed in fed-batch mode. We explained this phenomenon as a feature of EnBase fed-batch mode which supports high cell density by a slow release of an essential nutrient (glucose).

As the enhancing effect on cell density is correlated with protein production, regarding proteins with innate toxicity the optimum condition may be achieved in a moderately increased cell density. In other words, by reducing the culture temperature to $25^{\circ} \mathrm{C}$ the cytotoxic effect was diminished along with the decrement in maximum cell densities. On the other side, LB conventional batch cultivation mode was unable to support high cell densities in any of the investigated temperatures and the exogenous $\alpha$-Luffin toxin production in basic levels was basically enough for cytotoxic effect on $E$. coli cells.

The amino acid sequence disclosed by Kataoka et al. (38) was used as a basis for gene synthesis after $E$. coli codon usage optimization to avoid the codon bias effect on expression yield (39). The sequence applied here was lacking signal sequence and extended to the amino acid 261 of $\alpha$-Luffin. As the NdeI cloning site was used in the upstream part, an N-terminal His-tag of 13 amino acids was added to the final protein sequence. Hence, the final size of Histidine tagged $\alpha$-Luffin was approximately $28.8 \mathrm{kDa}$.

The most common route in industrial production of recombinant proteins is cytoplasmic biosynthesis. However, in this way due to the lack of efficient folding systems most of the exogenous protein molecules are expressed in insoluble inclusion body format. Considering the costly and complicated refolding process which usually results in low final recoveries it is of great value to implement methods so as to reach higher soluble protein ratios.

Various strategies have been practiced to promote soluble protein formation. They are categorized in two distinct groups; first strategies which are focused on protein engineering as truncation (40), mutation (41) and using fusion tags (42). Second strategies which do not engineer the target molecule but focus on media (28), buffering (32), cultivation temperature optimization (27) as well as utilizing engineered strains and co expression of chaperons (29).

Here, with the aim of an efficient production of $\alpha$-Luffin in a soluble format, a special fed-batch cultivation mode which provides media optimization besides optimized buffering system was investigated. Moreover, two different cultivation temperatures were studied at different intervals during $24 \mathrm{~h}$ incubation time.

During the special fed-batch cultivation mode applied in the project, the continuous feeding with glucose and the optimum buffering condition prevented early cell death due to byproduct accumulation and/or nutrient deficiency. Thus, a distinct rise in cell densities was observed in fed-batch compared to conventional batch mode of culture at induction time. As shown in Figure 2, there were 8 and 24 fold rises in induction $\mathrm{OD}_{600}$ values for 25 and $30{ }^{\circ} \mathrm{C}$ temperatures compared to their corresponding batch mode cultivation. The cells were able to climb up to maximum $\mathrm{OD}_{600}$ values of 22 and 26.5 in 25 and $30^{\circ} \mathrm{C}$, respectively.

In a previous study, using EnBase system conducted by Panula-Perälä et al., lower total productivity per cell was reported compared to standard batch medium whereas higher volumetric protein yield and a higher proportion of TIM (triosephosphate isomerase) in the soluble form was achieved which may be due to the drastically higher cell density (34).

Nevertheless, as other studies have proposed (40) in spite of higher achieved cell densities at the end of each cultivation, the specific productivity showed slight increase (Fig. 3). On the other hand, significant difference in cell densities of fed-batch in comparison to its parallel batch mode revealed its effect on the volumetric production of cells. As represented in Figure 3, fed-batch cultures showed higher production of recombinant $\alpha$-Luffin per cell.

Considering our protein characteristics besides EnBase system special features, 30 and $25{ }^{\circ} \mathrm{C}$ temperatures were studied. The $30{ }^{\circ} \mathrm{C}$ was chosen based on recommended EnBase protocol due to higher oxygen solubility and reduced evaporation while studying usual nontoxic proteins expression $(25,43)$. Here also, this temperature resulted in higher specific production of total protein in both batch and fed-batch method (Figs. 3A and 3B). On the other side, since functional ribosomes are reported to be higher at lower 
temperatures (35) and our protein of interest has its inhibitory effect on ribosomes, $25^{\circ} \mathrm{C}$ was also applied to test expression profile under this condition.

In contrast to the reports by Liu (5), in batch culture, no distinct expression was achieved at this temperature of batch culture which could be because of minor sequence differences and/or higher toxicity of $\alpha$-Luffin (44, 45) (Fig. 3C). However, EnBase Flo fed-batch mode resulted in protein expression in all investigated hours after induction (Fig. 3D).

The relatively constant density of expressed bands on SDS-PAGE (Fig. 3) from equal cell concentrations demonstrated that incubation time did not strongly influence cellular specific production rate of the cells. However, it is obvious that high cell densities achieved in late incubation phases (Fig. 2) would have resulted in higher volumetric productivities.

As reported by Liling Liu, $\alpha$-Luffin expression formed more soluble fraction when expressed at 25 ${ }^{\circ} \mathrm{C}$ rather than 30 or $37{ }^{\circ} \mathrm{C}$ in batch culture (5). In this study, although no obvious expression of $\alpha$-Luffin was observed in batch mode at $25{ }^{\circ} \mathrm{C}$ temperature, a distribution of protein in both soluble and pellet fractions was seen in $30{ }^{\circ} \mathrm{C}$ batch mod (Figs. 4A and B). But in spite of partly soluble expression per cell, as cells were not able to reach high densities in batch compared to fed-batch mode (Fig. 1) the volumetric amount of soluble protein was not high.

By performing fed-batch cultivation at $30^{\circ} \mathrm{C}$, more soluble ratio was achieved during the early steps of incubation (Fig. 4B). However during the two final incubation times (12 and $24 \mathrm{~h}$ after induction) the soluble fraction was reduced. The reason for that could be the cell death effect as at this temperature of fedbatch cultivation the cells start their steady state $6 \mathrm{~h}$ after induction like what we observed in batch mode (Fig. 1). On the other hand, at this temperature the high optical density (18 and 23.2) achieved, before steady state, resulted in an acceptable soluble volumetric productivity as a whole.

Despite the efficiency of EnBase Flo, further optimization for each recombinant protein could be applied likewise any other cultivation systems.

\section{Conclusions}

In general, we proposed here the efficacy of EnBase fed-batch mode for the production of a toxic protein $(\alpha$-Luffin) that the cultivation temperature and incubation time should be well optimized for the special target proteins. Here, the early incubation time was preferable at $30{ }^{\circ} \mathrm{C}$ whereas at $25^{\circ} \mathrm{C}$ time extension of protein synthesis (12 and $24 \mathrm{~h}$ post induction) resulted in higher amount of soluble recombinant protein. What is more, the bacterial growth rate after boosting should be low enough to provide correct protein folding.

It is absolutely clear that EnBase fed-batch cultivation mode was able to promote improved cell densities and protein folding for $\alpha$-Luffin, a protein with innate toxic feature. It is very likely that the reduction in growth rate during the first overnight cultivation enhances correct folding and folding-assisting proteins are greatly involved in this procedure. All the same, the cellular mechanisms involved in this process are yet under question and investigation in our lab.

\section{Acknowledgments}

This study is sponsored by a grant from Biotechnology Research Center, Pasteur Institute of Iran.

\section{References}

1. Pelegrini PB, Murad AM, Silva LP, Dos Santos RC, Costa FT, Tagliari PD, et al. Identification of a novel storage glycinerich peptide from guava (Psidium guajava) seeds with activity against Gram-negative bacteria. Peptides. 2008;29(8):1271-9. DOI: $10.1016 /$ j.peptides.2008.03.013

2. Parkash $\mathrm{A}, \mathrm{Ng} \mathrm{TB}, \mathrm{Tso} \mathrm{WW}$. Isolation and characterization of luffacylin, a ribosome inactivating peptide with anti-fungal activity from sponge gourd (Luffa cylindrica) seeds. Peptides. 2002;23(6):1019-24. DOI: 10.1016/S0196-9781(02)00045-1

3. Au KY, Wang RR, Wong YT, Wong KB, Zheng YT, Shaw PC. Engineering a switch-on peptide to ricin A chain for increasing its specificity towards HIV-infected cells. Biochim Biophys Acta. 2014;1840(3):958-63. DOI: 10.1016/j.bbagen.2013.11.005

4. Cao Y, Marks JD, Huang Q, Rudnick SI, Xiong C, Hittelman $\mathrm{WN}$, et al. Single-chain antibody-based immunotoxins targeting Her2/neu: design optimization and impact of affinity on antitumor efficacy and off-target toxicity. Mol Cancer Ther. 2012;11(1):143-53. DOI: 10.1158/1535-7163.MCT-11-0519

5. Liu L, Wang R, He W, He F, Huang G. Cloning and soluble expression of mature alpha-luffin from Luffa cylindrica and its antitumor activities in vitro. Acta Biochim Biophys Sin. 2010;42(8):585-92. DOI: 10.1093/abbs/gmq056

6. Shin MC, Zhang J, DavidAE, Trommer WE, Kwon YM, Min KA, et al. Chemically and biologically synthesized CPP-modified gelonin for enhanced anti-tumor activity. $J$ Control Release. 2013;172(1):169-78. DOI: 10.1016/j.jconrel.2013.08.016

7. Benigni F, Canevari S, Gadina M, Adobati E, Ferreri AJ, Di Celle EF, et al. Preclinical evaluation of the ribosomeinactivating proteins PAP-1, PAP-S and RTA in mice. Int $J$ Immunopharmacol. 1995;17(10):829-39. DOI: 10.1016/01920561(95)00068-D

8. Shahidi-Noghabi S, Van Damme EJ, Smagghe G. Carbohydratebinding activity of the type-2 ribosome-inactivating protein SNA-I from elderberry (Sambucus nigra) is a determining factor for its insecticidal activity. Phytochemistry. 2008;69(17):29728. DOI: 10.1016/j.phytochem.2008.09.012

9. Kwon SY, An CS, Liu JR, Kwak SS, Lee HS, Kim JK, et al. Molecular cloning of a cDNA encoding ribosome inactivating protein from Amaranthus viridis and its expression in E. coli. Mol Cells. 2000;10(1):8-12. 
10. Lord JM, Roberts LM, Robertus JD. Ricin: structure, mode of action, and some current applications. Faseb J. 1994;8(2):2018.

11. Peumans WJ, Hao Q, Van Damme EJ. Ribosome-inactivating proteins from plants: more than RNA N-glycosidases? Faseb $J$. 2001;15(9):1493-506.

12. Bulbul IJ, Zulfiker AHM, Hamid K, Khatun MH, Begum Y. Comparative Study of In vitro Antioxidant, Antibacterial and Cytotoxic Activity of Two Bangladeshi Medicinal Plants- Luffa cylindrica L. and Luffa acutangula. Pharmacognosy Journal. 2011;3(23):59-66. DOI: 10.5530/pj.2011.23.9

13. Ma C, Li Y, Li Z, Huang H, Xu K, Xu H, et al. Synthesis and purification of a toxin-linked conjugate targeting epidermal growth factor receptor in Escherichia coli. Protein Expr Purif. 2012;83(1):1-7. DOI: 10.1016/j.pep.2012.02.011

14. Ng TB, Wong RN, Yeung HW. Two proteins with ribosomeinactivating, cytotoxic and abortifacient activities from seeds of Luffa cylindrica roem (Cucurbitaceae). Biochem Int. 1992;27(2):197-207.

15. Ng TB, Chan WY, Yeung HW. Proteins with abortifacient, ribosome inactivating, immunomodulatory, antitumor and antiAIDS activities from Cucurbitaceae plants. Gen Pharmacol. 1992;23(4):579-90. DOI: 10.1016/0306-3623(92)90131-3

16. Poma A, Marcozzi G, Cesare P, Carmignani M, Spano L. Antiproliferative effect and apoptotic response in vitro of human melanoma cells to liposomes containing the ribosomeinactivating protein luffin. Biochim Biophys Acta. 1999;1472(12):197-205. DOI: 10.1016/S0304-4165(99)00121-X

17. Flygare JA, Pillow TH, Aristoff P. Antibody-drug conjugates for the treatment of cancer. Chem Biol Drug Des. 2013;81(1):11321. DOI: $10.1111 /$ cbdd. 12085

18. Trail P. Antibody Drug Conjugates as Cancer Therapeutics. Antibodies. 2013;2(1):113. DOI:10.3390/antib2010113

19. Biswas H, Chattopadhyaya R. Thermal, chemical and $\mathrm{pH}$ induced unfolding of turmeric root lectin: modes of denaturation. PloS one. 2014;9(8):e103579. DOI: 10.1371/journal.pone.0103579

20. 20. Gadadhar S, Karande AA. Abrin immunotoxin: targeted cytotoxicity and intracellular trafficking pathway. PloS one. 2013;8(3):e58304. DOI: 10.1371/journal.pone.0058304

21. 21. Luster TA, Mukherjee I, Carrell JA, Cho YH, Gill J, Kelly L, et al. Fusion toxin BLyS-gelonin inhibits growth of malignant human $\mathrm{B}$ cell lines in vitro and in vivo. PloS one. 2012;7(10):e47361. DOI: 10.1371/journal.pone.0047361

22. Polito L, Bortolotti M, Mercatelli D, Battelli MG, Bolognesi A. Saporin-S6: a useful tool in cancer therapy. Toxins. 2013;5(10):1698-722. DOI: 10.3390/toxins5101698

23. Ng YM, Yang Y, Sze KH, Zhang X, Zheng YT, Shaw PC. Structural characterization and anti-HIV-1 activities of arginine/ glutamate-rich polypeptide Luffin P1 from the seeds of sponge gourd (Luffa cylindrica). J Struct Biol. 2011;174(1):164-72. DOI: $10.1016 /$ j.jsb.2010.12.007

24. Sanchez-Garcia L, Martín L, Mangues R, Ferrer-Miralles N, Vázquez E, Villaverde A. Recombinant pharmaceuticals from microbial cells: a 2015 update. Microb Cell Fact. 2016;15(1):33. DOI: 10.1186/s12934-016-0437-3

25. Krause M, Ukkonen K, Haataja T, Ruottinen M, Glumoff T, Neubauer A, et al. A novel fed-batch based cultivation method provides high cell-density and improves yield of soluble recombinant proteins in shaken cultures. Microb Cell Fact. 2010;9:11. DOI: 10.1186/1475-2859-9-11

26. Shamriz S, Ofoghi H, Amini-bayat Z. Soluble Expression of
Recombinant Nerve Growth Factor in Cytoplasm of Escherichia coli. Iran J Biotech. 2016;14(1):16-22. DOI: 10.15171/ijb.1331

27. Berrow NS, Bussow K, Coutard B, Diprose J, Ekberg M, Folkers GE, et al. Recombinant protein expression and solubility screening in Escherichia coli: a comparative study. Acta Crystallogr D Biol Crystallogr. 2006;62(Pt 10):1218-26. DOI: $10.1107 / \mathrm{S} 0907444906031337$

28. Sorensen HP, Mortensen KK. Soluble expression of recombinant proteins in the cytoplasm of Escherichia coli. Microb Cell Fact. 2005;4(1):1. DOI: 10.1186/1475-2859-4-1

29. Ikura K, Kokubu T, Natsuka S, Ichikawa A, Adachi M, Nishihara $\mathrm{K}$, et al. Co-overexpression of folding modulators improves the solubility of the recombinant guinea pig liver transglutaminase expressed in Escherichia coli. Prep Biochem Biotechnol. 2002;32(2):189-205. DOI: 10.1081/PB-120004130

30. Wulfing C, Pluckthun A. Correctly folded T-cell receptor fragments in the periplasm of Escherichia coli. Influence of folding catalysts. J Mol Biol. 1994;242(5):655-69. DOI: 10.1006/jmbi.1994.1615

31. Shimokawa-Falcao LH, Caporrino MC, Barbaro KC, DellaCasa MS, Magalhaes GS. Toxin Fused with SUMO Tag: A New Expression Vector Strategy to Obtain Recombinant Venom Toxins with Easy Tag Removal inside the Bacteria. Toxins. 2017;9(3). DOI: 10.3390/toxins9030082

32. Tartoff KD, Hobbs CA. Improved Media for Growing Plasmid and Cosmid Clones. Bethesda Research Laboratories Focus. 1987;9:12.

33. Jeude M, Dittrich B, Niederschulte H, Anderlei T, Knocke C, Klee D, et al. Fed-batch mode in shake flasks by slow-release technique. Biotechnol Bioeng. 2006;95(3):433-45. DOI: 10.1002/bit.21012

34. Panula-Perala J, Siurkus J, Vasala A, Wilmanowski R, Casteleijn MG, Neubauer P. Enzyme controlled glucose auto-delivery for high cell density cultivations in microplates and shake flasks. Microb Cell Fact. 2008;7:31. DOI: 10.1186/1475-2859-7-31

35. Yun HS, Hong J, Lim HC. Regulation of ribosome synthesis in Escherichia coli: effects of temperature and dilution rate changes. Biotechnol Bioeng. 1996;52(5):615-24. DOI: 10.1002/(SICI) 1097-0290(19961205)52:5<615::AIDBIT9>3.0.CO;2-M

36. Chaddock JA, Lord JM, Hartley MR, Roberts LM. Pokeweed antiviral protein (PAP) mutations which permit E.coli growth do not eliminate catalytic activity towards prokaryotic ribosomes. Nucleic Acids Res. 1994;22(9):1536-40.

37. Girbes T, Barbieri L, Ferreras M, Arias FJ, Rojo MA, Iglesias R, et al. Effects of ribosome-inactivating proteins on Escherichia coli and Agrobacterium tumefaciens translation systems. $J$ Bacteriol. 1993;175(20):6721-4. DOI: 10.1128/jb.175.20

38. Kataoka J, Habuka N, Miyano M, Masuta C, Koiwai A. Nucleotide sequence of cDNA encoding alpha-luffin, a ribosome-inactivating protein from Luffa cylindrica. Plant Mol Biol. 1992;18(6):1199-202.

39. Gustafsson C, Govindarajan S, Minshull J. Codon bias and heterologous protein expression. Trends Biotechnol. 2004;22(7):346-53. DOI: 10.1016/j.tibtech.2004.04.006

40. Mahboudi F, Barkhordari F, Godarzi RM, Enayati S, Davami F. A fed-batch based cultivation mode in Escherichia coli results in improved specific activity of a novel chimeric-truncated form of tissue plasminogen activator. $J$ Appl Microbiol. 2013;114(2):364-72. DOI: 10.1111/jam.12059

41. Gilabert-Oriol R, Thakur M, Weise C, Dernedde J, von 


\section{Barkhordari $\mathrm{F}$ et al.}

Mallinckrodt B, Fuchs H, et al. Small structural differences of targeted anti-tumor toxins result in strong variation of protein expression. Protein Expr Purif. 2013;91(1):54-60. DOI: 10.1016/j.pep.2013.07.004

42. Chopra AK, Brasier AR, Das M, Xu XJ, Peterson JW. Improved synthesis of Salmonella typhimurium enterotoxin using gene fusion expression systems. Gene. 1994;144(1):81-5.

43. Rezaie F, Davami F, Mansouri K, amiri SA, Fazel R, Mahdian $\mathrm{R}$, et al. Cytosolic expression of functional Fab fragments in E. coli using a novel combination of dual SUMO expression cassette and EnBase ${ }^{\circledR}$ cultivation mode. J Appl Microbiol. 2017; n/a-n/a. DOI: 10.1111/jam.13483

44. Li F, Yang XX, Xia HC, Zeng R, Hu WG, Li Z, et al. Purification and characterization of Luffin P1, a ribosomeinactivating peptide from the seeds of Luffa cylindrica. Peptides. 2003;24(6):799-805. DOI: 10.1016/S0196-9781(03)00173-6

45. Stirpe F, Barbieri L. Ribosome-inactivating proteins up to date. FEBS Lett. 1986;195(1-2):1-8. DOI: 10.1016/00145793(86)80118-1 